\title{
Analysis of Genetic Diversity among Brassica juncea Genotypes using Morpho-physiological and SSR Markers
}

\author{
Kanchan Verma ${ }^{1}$, Manoj Kumar Tripathi ${ }^{1 *}$, Sushma Tiwari ${ }^{1}$ and Niraj Tripathi ${ }^{2}$
}

${ }^{1}$ Department of Plant Molecular Biology and Biotechnology, College of Agriculture, Rajmata

Vijyaraje Scindia Krishi Vishwa Vidyalaya, Gwalior, M.P., India

${ }^{2}$ Direcorate of Research Services, Jawaharlal Nehru Krishi Vishwa Vidyalaya, Jabalpur, M.P., India

*Corresponding author

\section{A B S T R A C T}

\section{Keywords}

Genetic diversity, Genotypes,

Molecular markers,

Mustard,

Phenotypic variance

Article Info

Accepted:

12 December 2020

Available Online:

10 January 2021
Indian mustard has the share of over $80 \%$ to the total rapeseed-mustard production in the country. Present investigation is conducted to guesstimate the possible presence of diversity among 38 germplasm lines and 5 cultivated varieties of Indian mustard by using 12 morpho-physiological parameters as well as microsatellite markers. Phenotypic analysis of variance for 12 yield and its attributing traits revealed that, the genotypes taken for this investigation had significant amount of genetic variation. Variances due to genotypes were highly significant for all the characters except numbers of primary branches per plant, siliqua length, numbers of seeds/siliqua and 1000-seed weight. In our study, a total of eleven polymorphic SSR molecular markers were used and showed sufficiently high sensitivity to detect DNA polymorphisms. Information generated from the current study would be helpful in the improvement of Indian mustard by the means of conventional and/or molecular breeding in impending days.

\section{Introduction}

Brassica juncea is the valuable oilseed crop after soybean and palm oil. It is also considered as the second largest source of protein after soybean and consumption of each part of plant by human as well as animals. Due to certain other qualities of mustard seeds which contain $30-46 \%$ oil with good amount of protein content (17-22.0\%), the oil became popular in India. Indian mustard is also an important component in the oilseed sector of the country. Indian people consume B. Juncea in the form of oil however it is also important for livestock feed. Oil consumption has increased due to budding population and improving life standards. So, the present oil requirements can be fulfilled through increment in the yield potential of $B$. juncea using breeding approaches. Genetic diversity decides the use of two parents for hybridization purposes.

Genetic assortment allows the populations to adapt in changing environment. The basic exercise of the evaluation of inherent 
variability in a particular crop species is required to start any breeding programme. An array of techniques is available now days for the identification of variability in crop plants including morpho-physiological, biochemical and molecular markers (Mohammadi and Prasanna, 2003).

Reports are also available on the assessment of diversity in B. juncea using different approaches (Vaishnava et al., 2006; Alie et al., 2009; Shyam and Tripathi, 2019; Shyam et al., 2020).

Amongst the diverse types of molecular markers employed, microsatellites are advantageous due to their higher reproducibility, co-dominance nature and abundance, wide distribution throughout the genome, easy storability and multi-allelic variation (Powell et al., 1996). The strengths of SSR markers are by reason of its presence in soaring numbers in eukaryotes. Furthermore, it can be functional even with low quantities of template DNA.

In addition to that, it is an improved technique which is simpler and more efficient to find polymorphism (Tiwari et al., 2019) but some of the breeding groups advocate morphological traits than molecular markers (Hu et al., 2007; Kachare et al., 2019; Mishra et al., 2020; Upadhyay et al., 2020) as a result, present investigation is carried to estimate the diversity present among thirtyeight germplasm lines and 5 cultivated varieties of Indian mustard at molecular level and to assess the genetic relationship within and between genotypes by using 12 different morpho-physiological parameters as well as SSR molecular markers.

The intent was to combine the relative efficiency of both approaches to lead into a more informative result for characterization of genotypes of $B$. juncea.

\section{Materials and Methods}

\section{Experimental materials}

A total of 38 germplasm lines and 5 cultivated varieties (Table 1) of B. juncea were preferred for phenotypic and molecular analysis. These germplasm lines are currently being cultivated in Morena district and various adjoining regions of Gwalior district of Madhya Pradesh and some of them are also cultivated in different agro-climatic zones across India. The seed of germplasm lines were collected from Zonal Agricultural Research Station, Morena, Rajmata Vijayaraje Scindia Agricultural University, Gwalior, India.

\section{Phenotypic characterization}

In the field evaluation trial, a total of 43 genotypes were evaluated in Random Block Design. The mpho-physiological data were recorded on 12 different yield attributing traits and were subjected to the analysis of variance (ANOVA).Standard error (S.E.) and critical difference (CD) were estimated using SPSSV19 software. The coefficient of correlation among all morpho-physiological traits at maturity was calculated manually using formulae in MS Excel. Based on similar coefficient, dendrogram was constructed using NTSYS-pc v2.1(Rohlf, 2000).

\section{Molecular analysis}

Young leaves were taken from 20 days-old plants of each genotype for DNA extraction. Genomic DNA was extracted by following the protocol described by Doyle and Doyle (1990) with required modifications. Purification was carried out to get RNA free DNA samples using RNaseA and quantification were carried out using $0.8 \%$ agarose gel. A total of 11 SSR primers (Table 2 ) were selected from published resources to express polymorphism among Indian mustard 
genotypes. Polymerase chain reaction was performed in a total $10 \mu$ reaction volume in the Applied Biosystem Gradient Thermal Cycler. The composition of the reaction mixture was: $1.0 \mu \mathrm{l}$ of $(25 \mathrm{ng} / \mu \mathrm{l})$ of DNA template, $1.0 \mu \mathrm{l}$ of $10 \mathrm{x}$ PCR buffer, 5 pmol of each primer, $0.2 \mathrm{mM}$ dNTP mix, $0.1 \mu \mathrm{l}$ of Taq DNA polymerase, $0.5 \mu \mathrm{l}$ of $\mathrm{MgCl}_{2}, 6.1 \mu \mathrm{l}$ nuclease free water and final volume was made up the $10 \mu \mathrm{l}$. Polymerase chain reactions was carried out with following programme: one cycle of initial denaturation at $94{ }^{\circ} \mathrm{C}$ for $4 \mathrm{~min}$; thirty-five cycles of denaturation at $94{ }^{\circ} \mathrm{C}$ of $30 \mathrm{~s}$, annealing for $30 \mathrm{~s}$, extension at $72^{\circ} \mathrm{C}$ for $45 \mathrm{~s}$ min. The final extension of one cycle at $72{ }^{\circ} \mathrm{C}$ for $10 \mathrm{~min}$ was done before storage at $4^{\circ} \mathrm{C}$. The amplified fragments were resolved on $3 \%$ agarose gel. Electrophoresed gels were documented under Gel Documentation System. Band sizes were determined by 100 bp DNA ladder. Bands were scored according to their size in base pair. Data was used to construct dendrogram using Power marker v3.25 (Liu and Muse, 2005). The analysis of major allelic frequency, polymorphism information content and genetic distancebased clustering were performed.

\section{Results and Discussion}

\section{Morpho-physiological analysis}

The analysis of variance for 12 yield and its attributing traits revealed presence of considerable amount of variation among different genotypes taken for present investigation (Table 2). The lowest and highest values for each character were recorded along with the mean performance which is also referred to as range. Plant height (cm), days to $50 \%$ flowering (DAS), days to maturity (DAS), main raceme length $(\mathrm{cm})$, number (s) of primary branches/plant, number (s) of secondary branches/plant, siliqua length $(\mathrm{cm})$, numbers of seeds/siliqua, number(s) of siliqua/plant, 1000-seed weight (g), seed yield per plant (g) and harvest index (\%) showed a wider range for trait values. The most important agronomic trait, seed yield per plant, showed a range between $5.0 \mathrm{~g}$ to $16.0 \mathrm{~g}$ (Table 3). The results observed were similar to the results reported by Vinu et al., (2013) especially the most important seed yield per plant which showed a range between $5.90 \mathrm{~g}$ to $15.59 \mathrm{~g}$. Results reported by Singh and Bhajan (2016) are also in accordance with the findings of present research. The study demonstrated that, variances due to replication were highly significant for plant height, main raceme length and number(s) of siliqua per plant; variances due to varieties were also found highly significant different for all the characters except number(s) of primary branches per plant, siliqua length, number(s) of seeds / siliqua and 1000-seed weight. Significant differences among the progenies/genotypes for all the traits investigated have been reported earlier (Singh and Bhajan, 2016).

Morpho-physiological data analysis divided the genotypes into two clusters viz., CI and CII. Cluster C-I divided into CI-A which further divided into CI-A(i) and CI-A(ii), cluster CI-A(i) consists of genotypes MRNJ41, MRNJ-43, MRNJ-44, MRNJ-42, MRNJ46, MRNJ-52, MRNJ-49, MRNJ-48, MRNJ55, MRNJ-75, MRNJ-63, MRNJ-65, MRNJ73, MRNJ-67, MRNJ-68, MRNJ-57, MRNJ58, MRNJ-74, MRNJ-59, MRNJ-71, MRNJ72, NRCHB-101and PM-30. It is also observed that NRCHB-101 shares close relationship with MRNJ-72 however, cluster CI-A (ii) consists of germplasm lines i.e.: MRNJ-45, MRNJ-47, MRNJ-53, MRNJ-61, MRNJ-62, MRNJ-70, MRNJ-64, MRNJ-80, MRNJ-60, MRNJ-78, MRNJ-56, MRNJ-77, MRNJ-79 and cultivated variety GM-2. Cluster CI-B consists of MRNJ-50 and MRNJ-51 (Fig.1, Table 4). In the dendrogram $\mathrm{C}$-II is consisting of two cultivated varieties 
namely: Rohini and JM-3 and a germplasm line: MRNJ-54 and all of three separated from the cluster C-I.

\section{SSR marker analysis}

In our study, a total of 65 alleles were identified. The genotype and allele number(s) per locus varied from 3-12. Maximum numbers of alleles were amplified with SR_9222 while minimum 3 with CN-52 (B16) and SORF-73 (B-27) markers. The mean value for polymorphic markers was 5.99. The results of present study conducted showed somewhat resemblance with the study conducted by Qu et al., (2012) using 217 genotypes and 37 markers, as the markers were referred from the similar research work. They observed 2 to 11 alleles at each locus with an average of 5.29 per marker whereas the polymorphism varied from $16.67 \%$ to $100 \%$, however, they reported SR_9222 with $50 \%$ polymorphism and 6 numbers of alleles per locus it turned out to be the best marker in the present study may be due to the differences in germplasm lines taken, but surely the marker showed significant polymorphism and can be applied in crop improvement programmes in future.

Table.1 List of mustard germplasm lines and varieties with their collection source

\begin{tabular}{|c|c|c|c|c|c|}
\hline $\begin{array}{l}\text { S. } \\
\text { No. }\end{array}$ & $\begin{array}{l}\text { Germplasm } \\
\text { lines }\end{array}$ & Source & $\begin{array}{l}\text { S. } \\
\text { No. }\end{array}$ & $\begin{array}{l}\text { Germplasm } \\
\text { lines }\end{array}$ & Source \\
\hline 1. & MRNJ-41 & \multirow{12}{*}{$\begin{array}{l}\text { Directorate of Rapeseed- } \\
\text { Mustard } \\
\text { Bharatpur }\end{array}$} & 24. & MRNJ-64 & \multirow{13}{*}{$\begin{array}{l}\text { Farmer's field of District } \\
\text { Morena and adjoining areas }\end{array}$} \\
\hline 2. & MRNJ-42 & & 25. & MRNJ-65 & \\
\hline 3. & MRNJ-43 & & 26. & MRNJ-67 & \\
\hline 4. & MRNJ-44 & & 27. & MRNJ-68 & \\
\hline 5. & MRNJ-45 & & 28. & MRNJ-70 & \\
\hline 6. & MRNJ-46 & & 29. & MRNJ-71 & \\
\hline 7. & MRNJ-47 & & 30. & MRNJ-72 & \\
\hline 8. & MRNJ-48 & & 31. & MRNJ-73 & \\
\hline 9. & MRNJ-49 & & 32. & MRNJ-74 & \\
\hline 10. & MRNJ-50 & & 33. & MRNJ-75 & \\
\hline 11. & MRNJ-51 & & 34. & MRNJ-76 & \\
\hline 12. & MRNJ-52 & & 35. & MRNJ-77 & \\
\hline 13. & MRNJ-53 & \multirow{11}{*}{$\begin{array}{l}\text { Farmer's field of District } \\
\text { Morena and adjoining areas }\end{array}$} & 36. & MRNJ-78 & \\
\hline 14. & MRNJ-54 & & 37. & MRNJ-79 & \multirow{2}{*}{$\begin{array}{l}\text { Directorate of } \begin{array}{l}\text { Rapeseed- } \\
\text { Mustard } \\
\text { Bharatpur }\end{array} \\
\text { Research, }\end{array}$} \\
\hline 15. & MRNJ-55 & & 38. & MRNJ-80 & \\
\hline 16. & MRNJ-56 & & \multicolumn{3}{|c|}{ Varieties } \\
\hline 17. & MRNJ-57 & & 39. & Rohini & Kanpur, UP \\
\hline 18. & MRNJ-58 & & 40. & JM-3 & Morena \\
\hline 19. & MRNJ-59 & & 41. & GM-2 & Gujarat \\
\hline 20. & MRNJ-60 & & 42. & NRCHB-101 & DRMR, Bharatpur \\
\hline 21. & MRNJ-61 & & 43. & PM-30 & IARI, New Delhi \\
\hline 22. & MRNJ-62 & & & & \\
\hline 23. & MRNJ-63 & & & & \\
\hline
\end{tabular}


Table.2 Analysis of variance for yield and its attributes traits

\begin{tabular}{|c|c|c|c|c|c|c|c|c|c|c|c|c|c|}
\hline $\begin{array}{l}\text { Source of } \\
\text { variation }\end{array}$ & DF & $\begin{array}{l}\text { Plant } \\
\text { height } \\
\text { (cm) }\end{array}$ & $\begin{array}{l}\text { Days to } \\
50 \% \\
\text { flowering }\end{array}$ & $\begin{array}{l}\text { Days to } \\
\text { Maturity }\end{array}$ & $\begin{array}{l}\text { Mean } \\
\text { raceme } \\
\text { length } \\
(\mathrm{cm})\end{array}$ & $\begin{array}{l}\text { Numbers } \\
\text { of } \\
\text { Primary } \\
\text { branches/ } \\
\text { plant }\end{array}$ & $\begin{array}{l}\text { Numbers of } \\
\text { secondary } \\
\text { branches/ } \\
\text { plant }\end{array}$ & $\begin{array}{l}\text { Siliqua } \\
\text { length } \\
(\mathrm{cm})\end{array}$ & $\begin{array}{l}\text { Numbe } \\
\text { rs of } \\
\text { seeds / } \\
\text { siliqua }\end{array}$ & $\begin{array}{l}\text { Numbers } \\
\text { of } \\
\text { Siliqua/ } \\
\text { plant }\end{array}$ & $\begin{array}{l}1000- \\
\text { seed } \\
\text { weight } \\
\text { (g) }\end{array}$ & $\begin{array}{l}\text { Seed } \\
\text { yield/ } \\
\text { plant } \\
\text { (g) }\end{array}$ & $\begin{array}{l}\text { Harvest } \\
\text { index }(\%)\end{array}$ \\
\hline Replication & 1 & $70.74 * *$ & 0.19 & 0.57 & $13.44 * *$ & 2.28 & 0.05 & 1.19 & 1.67 & $951.12 * *$ & 0.49 & 0.04 & 0.03 \\
\hline Varieties & 42 & $292.36^{* *}$ & $57.67 * *$ & $320.33^{* *}$ & $120.38 * *$ & 0.91 & $4.95 *$ & 0.34 & 3.55 & $2674.71 * *$ & 1.29 & $11.19 *$ & $14.42 * *$ \\
\hline Error & 42 & $31.91 * *$ & $2.26 * *$ & $2.90 * *$ & $4.82 * *$ & 0.47 & 0.93 & 0.11 & $1.70 *$ & $79.04 * *$ & 0.21 & 0.63 & 0.12 \\
\hline
\end{tabular}

*, ** significant at 5 and $1 \%$ level of significance respectively

Table.3 Summary of Statistical analysis for morpho-physiological traits studied using SPSS V.19 software

\begin{tabular}{|c|c|c|c|c|c|c|c|c|c|c|c|c|}
\hline $\begin{array}{l}\text { Parameters/ } \\
\text { Characters }\end{array}$ & PH & DF & DM & MRL & NPB & NSB & SL & NS & NSP & TGW & GY & HI \\
\hline Mean & 195.63 & 41.28 & 122.37 & 72.05 & 4.70 & 5.81 & 4.53 & 13.63 & 173.81 & 5.60 & 10.44 & 21.21 \\
\hline SE of Mean & 1.84 & 0.82 & 1.93 & 1.18 & 0.10 & 0.24 & 0.06 & 0.20 & 5.58 & 0.12 & 0.36 & 0.41 \\
\hline SD & 12.09 & 5.37 & 12.68 & 7.76 & 0.67 & 1.57 & 0.41 & 1.33 & 36.57 & 0.80 & 2.37 & 2.69 \\
\hline Variance & 146.18 & 28.84 & 160.82 & 60.19 & 0.45 & 2.48 & 0.17 & 1.78 & 1337.36 & 0.65 & 5.60 & 7.21 \\
\hline Range & 58 & 27 & 42 & 38 & 4 & 7 & 2 & 6 & 206 & 4 & 11 & 11 \\
\hline Minimum & 162 & 29 & 99 & 57 & 4 & 4 & 4 & 11 & 109 & 4 & 5 & 16 \\
\hline
\end{tabular}

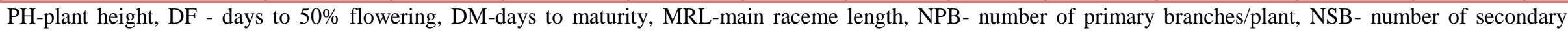
braches/plant,

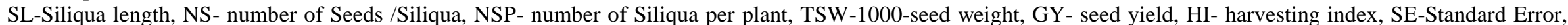

SD-Standard Deviation 
Table.4 Polymorphic Information Content and Statistical Details of SSR markers

\begin{tabular}{|c|c|c|c|c|c|c|}
\hline Marker & $\begin{array}{c}\text { Forward sequence } \\
5,-3,\end{array}$ & $\begin{array}{c}\text { Reverse sequence } \\
5^{\prime}-3^{\prime}\end{array}$ & $\begin{array}{c}\text { Major } \\
\text { Allele } \\
\text { Frequency }\end{array}$ & $\begin{array}{c}\text { Allele } \\
\text { Number }\end{array}$ & $\begin{array}{c}\text { Gene } \\
\text { Diversity } \\
(\%)\end{array}$ & PIC \\
\hline SR_9222 & $\begin{array}{l}\text { CACCGAACAAAA } \\
\text { CTGAGGGT }\end{array}$ & $\begin{array}{l}\text { CGTTTCACTGCGT } \\
\text { TCTACCA }\end{array}$ & 0.1628 & 12 & 88.75 & 0.8768 \\
\hline BRMS_324 & $\begin{array}{l}\text { AACTTAACCGAA } \\
\text { ACCGAGSTAGG }\end{array}$ & $\begin{array}{l}\text { AATCTCGAAATT } \\
\text { CATCGACTTCC }\end{array}$ & 0.2093 & 7 & 83.72 & 0.8160 \\
\hline SR_7223 & $\begin{array}{l}\text { AGGACCCGACTT } \\
\text { TCCTTGTT }\end{array}$ & $\begin{array}{l}\text { ACCAAACTCGGC } \\
\text { GTACAAAT }\end{array}$ & 0.3023 & 6 & 78.42 & 0.7517 \\
\hline $\begin{array}{l}\text { SSR_Na10D0 } \\
9\end{array}$ & $\begin{array}{l}\text { AAGAACGTCAAG } \\
\text { ATCCTCTGC }\end{array}$ & $\begin{array}{l}\text { ACCACCACGGTA } \\
\text { GTAGAGCG }\end{array}$ & 0.4884 & 5 & 68.69 & 0.6475 \\
\hline BRMS-240 & $\begin{array}{l}\text { CAAGAGTATTTG } \\
\text { TGTGGGTTGAC }\end{array}$ & $\begin{array}{l}\text { AAATAACGAACG } \\
\text { GAGAGAGAGG }\end{array}$ & 0.3721 & 5 & 75.39 & 0.7165 \\
\hline $\begin{array}{l}\text { SSR_Na10- } \\
\text { D11 }\end{array}$ & $\begin{array}{l}\text { GAGACATAGATG } \\
\text { AGTGAATCTGGC }\end{array}$ & $\begin{array}{l}\text { CATTAGTTGTGG } \\
\text { ACGGTCGG }\end{array}$ & 0.4419 & 6 & 68.36 & 0.6330 \\
\hline SR_94102 & $\begin{array}{l}\text { ATCСССАААСТА } \\
\text { СССТСАСС }\end{array}$ & $\begin{array}{l}\text { AGGATGAGCAAA } \\
\text { GGAAAGCA }\end{array}$ & 0.4419 & 4 & 67.82 & 0.6219 \\
\hline BRMS-093 & $\begin{array}{l}\text { TCCAAGTAGACC } \\
\text { GAATCAAGAGT }\end{array}$ & $\begin{array}{l}\text { ATAAATCGAACC } \\
\text { TGAAACCATGT }\end{array}$ & 0.3953 & 6 & 73.88 & 0.6986 \\
\hline CB-10065 & $\begin{array}{l}\text { CGGCAATAATGG } \\
\text { ACCACT }\end{array}$ & $\begin{array}{l}\text { CGGCTTTCACGC } \\
\text { AGACTTCG }\end{array}$ & 0.2093 & 8 & 84.91 & 0.8311 \\
\hline CN -52 (B-16) & $\begin{array}{l}\text { CCGGCTTGGTTC } \\
\text { GATACTT }\end{array}$ & $\begin{array}{l}\text { TTGCGAATCTTTA } \\
\text { AGGGACG }\end{array}$ & 0.1934 & 3 & 58.29 & 0.3219 \\
\hline $\begin{array}{l}\text { SORF-73 (B- } \\
\text { 27) }\end{array}$ & $\begin{array}{l}\text { CGTGGGCCAAGC } \\
\text { TTAGATTA }\end{array}$ & $\begin{array}{l}\text { CGTTCAAGAAGA } \\
\text { CACAGATCAAA }\end{array}$ & 0.1835 & 3 & 55.32 & 0.2957 \\
\hline \multicolumn{3}{|r|}{ Mean } & 0.3091 & 5.99 & 73.05 & 0.6555 \\
\hline
\end{tabular}

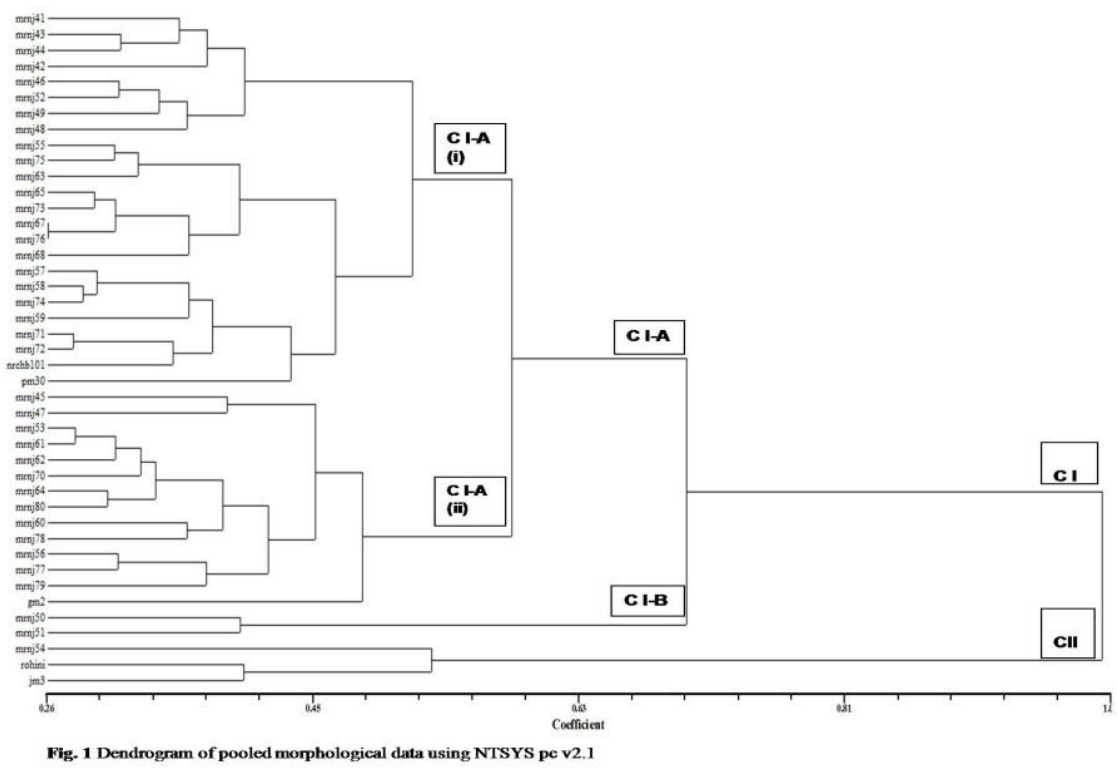


Fig.2 Gel image representing PCR product of SR_94102 with 43 mustard genotypes

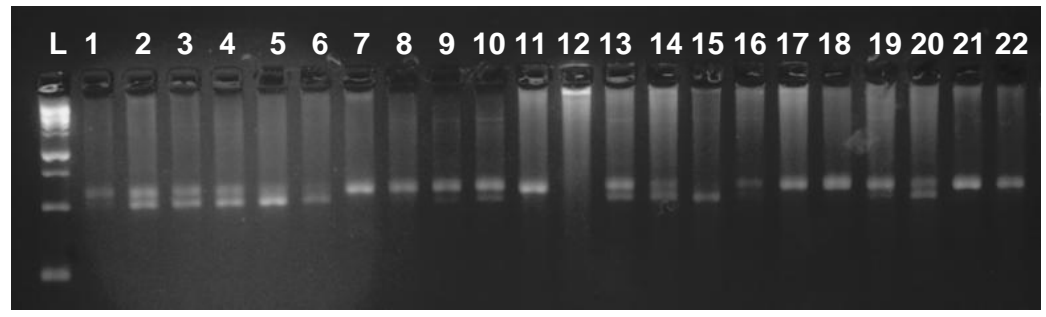

2425262728293031323334353637383940414243

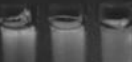

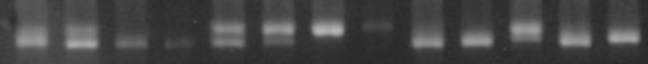

Fig.3 Dendrogram of mustard genotypes based on SSR data using Power marker software

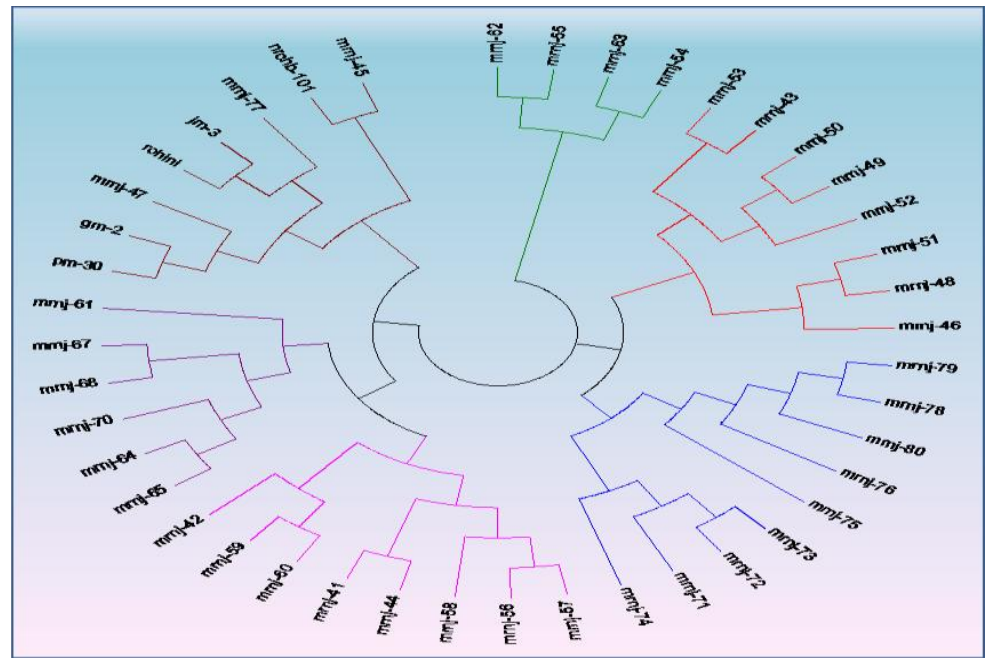

Microsatellites were used for DNA based diversity investigation among mustard genotypes successfully amplified with template DNA of studied genotypes. The multiple banding patterns (Fig. 2) were found with SSR markers in mustard cultivars. Similar reports are also available regarding appearance of multiple bands as the result of amplification of more than one locus by each SSR (Holton et al., 2002). This may be due to availability of multiple primer binding sites (Winter et al., 1999).
In our study, PIC value of the markers varied from minimum 0.2957 with primer SORF-73 (B-27) to a maximum 0.8768 with SR_9222 with an average of 0.6555 . The average PIC values were comparable as reported (Patel et al., 2018) where the PIC value ranged from $0.427-0.730$ with an average of 0.555 and Shyam et al., (2020) who reported polymorphism information content (PIC) value of the markers varied from minimum 0.51for SSR Na10-D07 to maximum 0.73 with primer BRMS-098 with a mean value of 
0.62 (Table 5). PIC values reported by Bharti et al., (2018) ranged from 0.34 to 0.49 with an average of 0.41 while Gupta et al., (2014) reported low PIC value 0.281 for SSR markers during their study on molecular diversity analysis of mustard. Lower PIC values may be attributed either due to less informative SSR markers, or slighter diversity amongst the tested genotypes. The mean PIC values ranged 0.38 to 0.96 were observed by Avatar et al., (2016), where the utmost value of PIC obtained was to some extent higher than our study. In our study, the selected 11 SSR markers showed polymorphism they showed sufficiently high sensitivity to detect DNA polymorphisms among the $43 \mathrm{~B}$. juncea germplasm lines and cultivars. The results obtained in the present study extended useful information. SSR markers are informative which could be utilized for characterization of germplasm lines. SSR has been effectively utilized as efficient tool for genetic characterization of many plant species including oilseed rape (Shyam et al., 2020).

The genetic relationships among mustard genotypes are presented in SSR based UPGMA tree. Major three clusters were obtained i.e., C-I, C-II and C-III, in which cluster $\mathrm{C}$-I consisted of germplasm lines MRNJ-62 and MRNJ-65 clustered together and MRNJ-63 and MRNJ- 54 in other. Cluster C-II was again divided into sub clusters 'C-II(a)' and 'C-II(b)', cluster C-II(a) consisted of MRNJ-53, MRNJ-43, MRNJ-50, MRNJ-49 and MRNJ-52 in one group and MRNJ-51, MRNJ-48 and MRNJ-46 in another, whereas C-II(b) consisted of MRNJ79, MRNJ-78, MRNJ-80, MRNJ-76 and MRNJ-75 in one group and MRNJ-73, MRNJ-72, MRNJ-71, MRNJ-74 in another group. Cluster C-III was divided into 2 subgroups C-III(a) consisting of MRNJ-57, MRNJ-56, MRNJ-58, MRNJ-44 and MRNJ41 in C-III a(i)I and MRNJ-60, MRNJ-59 and MRNJ-42 in C-IIIa(i)II. Germplasm lines
MRNJ-65, MRNJ-64, MRNJ-70, MRNJ-68 and MRNJ-67 fallen in C-IIIa(ii) I cluster and MRNJ-61 in C-III a(ii)II whereas C-IIIb consists of C-IIIb(i) in which PM-30, GM-2 and MRNJ-47in one group CIII b(i) I and Rohini, JM-3, MRNJ-77 in another naming $\mathrm{C}$-IIIb(ii)II. Other subgroup of the cluster CIII(b), i.e. C-IIIb (ii) consists of NRCHB-101 and MRNJ-45 (Fig 3). Earlier Qu et al., (2012) has also reported similar clustering after using SSR markers; the clustering was according to the known pedigrees. In another study Vinu et al., (2013) worked on assessment of genetic variability among Indian mustard genotypes using 134 microsatellites and obtained four major clusters. Different reports on clustering of mustard genotypes after application of microsatellites are available (Chen et al., 2011; Baghel et al., 2020). Clustering of genotypes shows a very diverse pattern according to genotypes and SSR markers.

It was clearly revealed from dendrogram that germplasm line MRNJ-54 falling with varieties Rohini and JM-3 and MRNJ-71 and MRNJ-72 with NRCHB-101 together there is possibility of existing many traits to be similar whereas the germplasm lines MRNJ50 and MRNJ-51 falling extremely apart from whole of the cluster shows the possibility of discovering new traits in them which could be further assisted in conventional and molecular breeding programmes. The dendrogram based on SSR data showed significant diversity; it grouped the genotypes into three clusters. The clusters were further divided into sub clusters revealing close relationships of MRNJ-47 with varieties PM-30 and GM-2 having the possibilities of similarity in many of the traits whereas MRNJ-77 showed close relationship with varieties Rohini and JM-3. MRNJ-45 shared close resemblance with NRCHB101.Germplasm lines MRNJ-62, MRNJ-65, MRNJ-63 and MRNJ-54 formed a separate cluster in dendrogram revealing entirely 
different genetic traits whereas through morpho-physiological cluster diagram, it was revealed that germplasm lines MRNJ-50 and MRNJ-51 are falling whole apart from the entire cluster indicating possibility of entirely different morpho-physiological traits. These unique germplasm lines could surely assist to give major support in the future molecular and conventional breeding programmes.

In conclusion the molecular profiling has been the preferred choice of breeding as these are more reliable and authentic and less influenced by environmental fluctuations. Therefore, SSR marker data described in this work would surely provide a useful starting point for further diversity analysis in future programmes aiming in mustard crop improvement at molecular level.

\section{Acknowledgement}

Authors would like to thanks the field technical staff members of Rajmata Vijayaraje Scindia Agricultural University, Gwalior for their help during field data collection.

\section{References}

Alie, F.A., Singh, T.T. and Sharma P.K. 2009. Genetic diversity analysis in Indian mustard [Brassica juncea (L.) czern \& coss]. Prog. Agric. Int. J. 9: 50.

Avtar, R., B. Rani, M. M. Jattan, N. Kumara and A. Rani. 2016. Genetic diversity analysis among elite gene pool of Indian mustard using SSR markers and phenotypic variations. The Bioscan 1(4): 30-35.

Baghel, R., Sharma, A.K., Tiwari, S., Tripathi, M.K. and Tripathi N. (2020) Genetic Diversity Analysis of Indian Mustard (Brassica spp.) Germplasm Lines using SSR Molecular Markers. Int. J. Curr. Microbiol. Appl. Sci. 9(12):
137-143.

Bharti, R., Chaoudhry, N., Sandhu, R., Gupta S.K. and Sharma, M. 2018. Molecular characterization of candidate gene in glucosinolate and erucic acid using SSR markers. Int. J. Ad. Res. Ideas Innov. Tech. 4(1): 24-54.

Chen, S., Wan, Z., Matthew, N.N., Chauhan, J.S., Lin, P., Redden, B. and Burton, W.A. 2011. Two distinct genetic diversity groups of oilseed Brassica juncea in both China and India Wagga Wagga NSW.

Doyle, J. J. and Doyle, J.L. 1990. Isolation of plant DNA from fresh tissue. Focus 12: 13.

Gupta, N., Zargar S.J., Gupta, M. and Gupta, S.K. 2014. Assessment of genetic variation in Indian Mustard (Brassica juncea L.) using PCR based markers. Mol. Plant Breed. 5(3): 10

Holton. T., John, C., Linda, B., Natalie, H. and Henry, R. 2002. Identification and mapping of polymorphic SSR markers from expressed gene sequences of barley and wheat. Centre for Plant Conservation Genetics Papers. 9. 10.1023/A:1026785207878.

Hu, S., Yu, C., Zhao, H., Sun, G., Zhao, S., Vyvadilova, M. and Kucera, V. 2007. Genetic diversity of Brassica napus L. germplasm from China and Europe assessed by some agronomically important characters. Euphytica 154: 9.

Kachare, S., Tiwari, S., Tripathi, N. and Thakur, V.V. 2019. Assessment of genetic diversity of soybean (Glycine $\max$ (L.) Merr.) genotypes using qualitative traits and microsatellite makers. Agric. Res. x: y-z. DOI: 10.1007/s40003-019-00412-y

Liu, K. and Muse, S.V. 2005. PowerMarker Integrated Analysis Environment for Genetic Marker Data. Bioinform. 21: 2128-2129.

Mohammadi, S.A. and Prasanna, B.M. 2003. 
Analysis of genetic diversity in crop plants salient statistical tools and considerations. Review \& Interpretation. Crop Sci. 43: 1235.

Patel, V., Yadav, R.C., Avtar, R., Jangra, S., Boken, G.D., Singh, S. and Yadav N.R. 2018. Genetic diversity analysis for salinity tolerance in Indian mustard [Brassica juncea (L.)] using SSR markers. Int. J. Curr. Microbiol. Appl. Sci. ISSN: 2319-7706.

Powell, W., Morgante, M., Andre, C., Hanafey, M., Tingey, S., Vogel, J. and Rafalski, A. 1996. The comparison of RFLP, RAPD, AFLP and SSR (microsatellite) markers for germplasm analysis. Mol. Breed. 2(3): 225.

Qu, C., Hasan, M., Lu, K., Liu, L. and Liu, X. 2012. Genetic diversity and relationship analysis of the Brassica napus germplasm using simple sequence repeat (SSR) markers. Afr. J. Bio. 11(27): 6923.

Rohlf, F.J. 2000. NTSYS-pc Numerical Taxonomy and Multivariate Analysis System Version 2.1. Exeter Publishing Setauket, New York.

Shyam, C. and Tripathi M.K. 2019. Biochemical studies in Indian mustard [Brassica juncea (Linn.) Czern \& Coss] for fatty acid profiling. Int. J. Chem. Stud. 7(4): 338-343.

Shyam, C., Tripathi, M.K., Tiwari, S., Tripathi, N. and Ahuja, A. 2020. Molecular characterization and identification of Brassica genotype (s) for low and high erucic acid content using SSR markers. Global J. Bio-Sci. Biotechnol. 9(2): 56-66.

Singh, V. and Bhajan, C.R. 2016. Evaluation of Indian mustard genotypes to heat stress in irrigated environment - seed yield stability and physiological model. J. Crop Sci. Biotechnol. 19: 333-339.

Tiwari, S., Tripathi, N., Tsuji, K. and Tantwai, K. 2019. Genetic diversity and population structure of Indian soybean (Glycine $\max$ (L.) Merr.) as revealed by microsatellite markers. Physiol. Mol. Biol. Plants 25(4):953-964.

Vaishnava, A., Sachan, J.N. and Tewari, S.K. 2006. Genetic divergence for important quantitative traits in Indian mustard (Brassica juncea (L.) Czern and Coss). Agri. Sci. Digest 26: 269.

Vinu, V., Singh, N., Vasudev, S., Yadava, D.K., Kumar, S., Naresh, S., Bhat, S.R. and Prabhu, K.V. 2013. Assessment of genetic diversity in Brassica juncea genotypes using phenotypic differences and SSR markers. Rev. Biol. Trop. 61(4): 1919.

Winter, P., Pfaff T., Udupa, S.M., Huttel, B., Sharma, P.C., Sahi, S., ArreguinEspinoza, R., Weigand, F., Muehlbauer, F.J. and Kahl, G. 1999. Characterization and mapping of sequence-tagged microsatellite sites in the chickpea (Cicer arietinum L.) genome. Mol. Gen. Genet. 262:90-101.

\section{How to cite this article:}

Kanchan Verma, Manoj Kumar Tripathi, Sushma Tiwari and Niraj Tripathi. 2021. Analysis of Genetic Diversity among Brassica juncea Genotypes using Morpho-physiological and SSR Markers. Int.J.Curr.Microbiol.App.Sci. 10(01): 1108-1117. doi: https://doi.org/10.20546/ijcmas.2021.1001.134 